\title{
Exposure to Organic Solvents and Breast Cancer in Women: A Hypothesis
}

\author{
France P. Labrèche, PhD, ${ }^{1,2 *}$ and Mark S. Goldberg, PhD ${ }^{2,3}$
}

\begin{abstract}
Incidence rates for breast cancer have increased steadily over the last 25 years, particularly among postmenopausal women. Secular changes in accepted and suspected risk factors can explain only a part of this increase. Given the increasing number of women in the workforce, it is possible that increases in breast cancer incidence may be caused by occupational exposure to hazardous agents. In particular, we hypothesize that organic solvents act directly as genotoxic agents or indirectly through their metabolites. Most organic solvents are highly lipophilic and are readily absorbed and distributed throughout the body via the bloodstream. Organic solvents are biotransformed mostly in the liver and the kidneys through a series of oxidative and reductive reactions, some of them resulting in bioactivation. There are indications of P-450 enzymatic oxidative activity in the breast parenchyma, but there appears to be limited detoxification of highly reactive metabolites. The physiology of the breast may also accentuate the accumulation of chemicals: breast parenchyma is embedded in a fat depot capable of storing lipophilic xenobiotics; it is conceivable that organic solvents and their metabolites, once stored in fat tissues, migrate to the breast parenchyma and are then transferred to the mammary lobules through continuous apocrine secretions. These secretions may reside in the ductular system long enough for the solvents and their bioactivated metabolites to locally exert detrimental effects. The evidence supporting this hypothesis is that many organic solvents have been detected in breast milk, the majority of carcinomas occur in the ductular system, and some organic solvents have been shown to produce mammary gland cancer in experiments on rodents. Further toxicological and epidemiologic studies are required to test this hypothesis, to elucidate the mechanisms, and to identify specific carcinogenic organic solvents. Am. J. Ind. Med. 32:1-14, 1997. () 1997 Wiley-Liss, Inc.
\end{abstract}

KEY WORDS: breast cancer; biotransformation; hypothesis; occupation; organic solvents; women

\section{INTRODUCTION}

Breast cancer is the most frequently occurring cancer among women. In Canada, for example, it accounts for

\footnotetext{
${ }^{1}$ Occupational and Environmental Health Unit, Montréal Public Health Department, Canada.

2Department of Occupational Health, McGill University, Montreal, Canada.

${ }^{3}$ Epidemiology and Biostatistics Unit, Institut Armand-Frappier, Université du Québec á Montréal, Laval, Québec, Canada.

Part of this paper was presented at the 10th International Symposium on Epidemiology in Occupational Health held in Como, Italy, September 1994.

*Correspondence to: Dr. France Labrèche, Occupational and Environmental Health Unit, Montréal Public Health Department, 75 de Port-Royal Est, Suite 240, Montréal (Québec) Canada H3L 3T1.

Accepted for publication 25 November 1996

$30.7 \%$ of all new cancer cases, and it is the second leading cause of cancer death in Canadian women [National Cancer Institute of Canada, 1996]. Although advances have been made in limiting the progression of female breast cancer through surgical and chemical adjuvant treatments, we are left with the grim picture that breast cancer incidence continues to increase unabated. In Canada, breast cancer incidence rates have increased by $27.9 \%$ over the last 25 years, with steeper increases observed in women 50 years and over [National Cancer Institute of Canada, 1993]; the age-standardized (to the standard World population) incidence rate now is 107 per 100,000 [National Cancer Institute of Canada, 1996]. Secular increases in incidence rates have also been observed in other jurisdictions (e.g., Connecticut, Denmark, Japan, the United Kingdom) [Coleman et al., 1993; Holford et al., 1991; Stevens et al., 1982]. It is 
estimated that about one in nine [National Cancer Institute of Canada, 1996] to one in 10 women [Campbell et al., 1994] will develop breast cancer during their lifetime.

The reasons for these increases in incidence are largely unknown. They do not appear to be due to changes in the pathologic definition of breast cancer or to an artifact of detecting "histologically malignant but biologically benign" tumors [Doll and Peto, 1987; Holford et al., 1991]. Part of the increase may be due, however, to early detection in mass screening programs operating in many western countries [Feuer and Wun, 1992; Swanson et al., 1993; Wun et al., 1995]. In addition, heightened awareness of the risks of breast cancer in the last few decades may have led to increased opportunities for early detection outside of dedicated screening programs. Secular changes in accepted and suspected risk factors (e.g., having fewer children and at later ages) may explain some of the long-term increases. It is likely that these risk factors can explain only a fraction of the incident cases [Kelsey, 1993; Rockhill et al., 1996], and probably cannot explain all of the increase in incidence rates.

While important contributions have been made in identifying potential risk factors, new directions for research are required. In recent years, a few studies have investigated risks associated with exposure to organochlorine pesticides and polychlorinated biphenyls (PCBs), both at the animal [Mason and Schulte, 1981; Ahlborg et al., 1995], and at the human [Wolff et al., 1993; Dewailly et al., 1994; Krieger et al., 1994] level, with no conclusive results yet [Ahlborg et al., 1995].

It has been recently hypothesized that exposures to exogenous carcinogens and breast tissue susceptibility to these exposures affect breast cancer incidence [Krieger, 1989]. As women have been entering the workforce in greater numbers since the 1960s [Statistics Canada, 1990], it is important to inquire whether occupational exposures may be linked to breast cancer incidence. Of particular concern are the organic solvents. These are widely used in the workplace and are also present in lower concentrations in ambient air and in potable water [Andrews and Snyder, 1991; Morris and Seifter, 1992]. In this paper we present the hypothesis that these lipophilic substances, and their metabolites, can migrate to adipose tissue in the breast where they can be stored, probably biotransformed in situ, and then excreted into the ductular systems where they may remain in contact with the parenchyma for significant amounts of time, thereby initiating or promoting carcinogenesis through genotoxic or related mechanisms. This hypothesis is different from that presented by Davis et al. [1993], where it was postulated that the estrogenic properties of halogenated hydrocarbons may be implicated in the etiology of breast cancer.

\section{Breast Parenchyma}

Breast parenchyma is made up of a series of apocrine glands, their primary function being to produce milk in lactating women. These epithelial cells are arranged into lobules (or acini) that are connected to a ductular system ending at the nipple. This glandular structure is embedded in fat and connective tissue serviced by an ample supply of blood and lymphatic vessels. There are a number of unique features of breast physiology that may render it more sensitive to the effect of organic solvents and their metabolites. First, the apocrine glands proliferate continuously from menarche, increasing their cell population over each ovulatory cycle, thus resulting in a continued development of the budding structure until about age 35 [Vorherr, 1974]. Breast tissue could thus be at high risk for mutations arising from DNA transcription and other errors during replication [Ames and Gold, 1990].

Physiologic changes during the menstrual cycle could enhance the accumulation of xenobiotics in the breast tissue. These are: 1) increased blood flow resulting in an increased accumulation of solvents or their lipophilic metabolites in the fat tissues surrounding the breast parenchyma; 2) secretion into the ductular system of colostrum-like fluid containing harmful xenobiotics (see below); and 3) epithelial cell death resulting in the release of substances that had accumulated in breast cells into extracellular spaces [Vorherr, 1974].

Petrakis demonstrated that fluids are secreted by the apocrine glands not only in the lactating but also in the non-lactating breast [Petrakis, 1986]. Secretions in the non-lactating breast have been inferred from the identification of lactoferrin, in concentrations similar to those found in colostrum and breast milk [Yap et al., 1981], and of lactose, alpha-lactalbumin, immunoglobulins, cholesterol, fatty acids, colostral cells, and breast epithelial cells. The secreted fluid is thought to be recycled through a continuous absorptive mechanism that makes the breast fluids seep through the ductal cells to the lymphatic vessels and the blood capillaries. Animal experiments in the 1950s demonstrated that fluids in the breast ducts of rabbits could make their way to the lymphatics surrounding the mammary gland [Petrakis, 1986]. There is evidence that this recycling process leads to bioaccumulation of endogenous and exogenous compounds, probably even more so for large molecules. For example, cholesterol and nicotine levels, along with their metabolites cholesterol epoxide and cotinine, have been found to be higher in breast fluid than in plasma, thereby indicating selective accumulation in ductular structures during the reabsorptive process [Petrakis et al., 1978, 1981]. In addition, a small study of apparently normal and neoplastic breast tissues showed higher levels of metabolites of organochlorine insecticides and PCBs in the breast tissue than in adjacent adipose tissue, for both normal and neoplastic 
TABLE I. Organic Solvents Detected in Human Milk

\begin{tabular}{llrll} 
Refs. & Organic solvent & Refs. & \multicolumn{1}{c}{ Organic solvent } \\
\hline a & Acetaldehyde & a & Ethyl methyl ketone \\
a & Benzaldehyde & a & $\beta$-Hexachlorocyclohexane \\
a & Benzene & a & Methyl alcohol (Methanol) \\
a-c & Carbon disulfide & a & Methyl amyl ketone (2-Heptanone) \\
c & Carbon tetrachloride & a & Methyl ethyl ketone \\
a & Chlorobenzene & a & Methyl isobutyl ketone \\
a & Chloroethane & a & Methyl propyl ketone \\
& $\quad$ (Ethyl chloride) & a & Methylene chloride \\
a & Chloromethane & a,c & Styrene \\
a & Chloropentane & a,b & Tetrachloroethylene \\
a & Crotonaldehyde & a & Toluene \\
a & Cyclohexane & a & 1,1,1-Trichloroethane (Methyl chloroform) \\
a & Cyclopentane & a & Trichloroethylene \\
a & Dichlorobenzene & a & Trichloromethane (Chloroform) \\
a & 1,2-Dichloroethane & a & Xylenes \\
c & Dichloroethylene & & \\
a & Ethyl alcohol & & \\
b & Ethylbenzene & & \\
& & &
\end{tabular}

aPellizzari et al., 1982.

bWolff, 1983.

c) ensen, 1991.

tissues [Wassermann et al., 1976]. Many solvents also have reportedly been detected in human milk [Coté et al., 1976; Pellizzari et al., 1982] (see Table I), often in higher concentrations than in the blood [Wolff, 1983]. Because of the reduced metabolic and clearance activity of breast tissue, by-products of metabolic oxidative and reductive processes could conceivably remain in contact with the parenchyma long enough to be able to act as early stage initiators, through alterations in DNA bases and other hydroxyl radical-induced adverse reactions [Malins et al., 1993], or as promoters to already initiated cells. This theory is consistent with the observation that about $70 \%$ of breast tumors originate in the ductular system [Berg and Hutter, 1995].

Although not specific to organic solvents, the hypothesis that exogenous carcinogens are secreted into breast fluids, is supported in part by anecdotal observations from a retrospective study among boat women of Aberdeen in Hong Kong. Traditionally, these women used to nurse their infants only from their right breast; the risk of developing cancer in the left breast, where milk would stagnate, was twice that of developing cancer in the right breast, and the ratio rose to 3:1 for women over 55 years of age [Petrakis, 1977a]. The effect of lactation on breast cancer is still not completely delineated, some studies showing no protective effect [Kvåle and Heuch, 1987; MacMahon et al., 1970; Thomas and Noonan, 1993], but some recent studies tend to show a slightly protective effect among premenopausal women after cumu- lative lactation of more than three months [Newcomb et al., 1994; Yuan et al., 1988]. Petrakis et al. [1980, 1982] showed that nipple aspirates (breast secretions and colostrum) can be mutagenic on the Ames test. They observed a higher proportion of positive Ames tests among pregnant farm workers than among pregnant women living in urban areas [Petrakis et al., 1982], a finding that is consistent with the assumption that farm workers have been more highly exposed to a variety of hazardous chemicals.

\section{Organic Solvents}

\section{Absorption and distribution}

Common to most organic substances are their volatility, their ability to dissolve a large array of materials, and their lipophilicity, although there is wide variability across organic solvents. Most of them are used as solvents per se, whereas some of them are used in chemical syntheses (e.g., monomers).

Organic solvents can enter the human body by ingestion, inhalation, and cutaneous absorption. Exposure can occur through food and water, from pollution of water sources and soil, or inadvertent contamination during processing or packaging [Agency for Toxic Substances and Disease Registry, 1992c, 1992h, 1993j]. Dermal absorption can be a significant route of entry when the skin is immersed in solvents [Sato and Nakajima, 1987] and, although this situation is usually avoidable, cutaneous contact may nevertheless be important in certain occupations. We assume here that inhalation is the primary route of exposure.

The toxicity of organic solvents is governed by the extent to which they are absorbed, distributed, and metabolized in the body. Whatever the route of entry, solvents will enter the bloodstream and will then migrate to different organs [Klaassen and Rozman, 1991]. The lung is the only organ in which all blood passes through; thereafter, about $75 \%$ of blood flow is directed to the vessel-rich tissues, with the liver receiving $25 \%$ of the total. Fat tissues and white bone marrow receive approximately $5 \%$ of the total flow [Sato and Nakajima, 1987].

The affinity of solvents for tissues and body fluids is described by partition coefficients. For any two media in equilibrium, the partition coefficient is defined as the ratio of the concentrations of the substance in the two tissues. Table II shows blood/air and fat/blood partition coefficients for some common organic solvents. Alcohols and ketones tend to have blood/air coefficients above 100 and fat/blood coefficients close to unity. This indicates that they are fairly hydrophilic: they will pass rapidly from inhaled air to the bloodstream, but their concentration in fat tissues will remain much lower than in blood. On the other hand, aromatic solvents (e.g., benzene, styrene, toluene, xylene) and halogenated solvents (e.g., methylene chloride, trichloroethylene, and tetrachloroethylene) are much more lipo- 
TABLE II. Partition Coefficients for Some Widely-Used Organic Solvents

\begin{tabular}{|c|c|c|c|}
\hline Reference & Solvent & $\begin{array}{l}\text { Blood/air } \\
\text { coefficient }\end{array}$ & $\begin{array}{l}\text { Fat/blood } \\
\text { coefficient }\end{array}$ \\
\hline Sato and Nakajima, 1987 & Acetone & 245 & 0.35 \\
\hline Sato and Nakajima, 1987 & Benzene & 7.7 & 63.1 \\
\hline Sato and Nakajima, 1987 & 2-Butanone (Methyl ethyl ketone) & 202 & 1.3 \\
\hline Sato and Nakajima, 1987 & Carbon tetrachloride & 2.4 & 150.4 \\
\hline Sato and Nakajima, 1987 & Chloroform & 10.3 & 38.9 \\
\hline Sato and Nakajima, 1987 & Cyclopropane & 0.4 & 22.2 \\
\hline Sato and Nakajima, 1987 & Dichlorobenzene (0-/m-) & $201-423$ & $94.3-134.8$ \\
\hline Sato and Nakajima, 1987 & 1,1-Dichloroethane & 4.7 & 39.8 \\
\hline Sato and Nakajima, 1987 & 1,2-Dichloroethane & 19.5 & 22.9 \\
\hline Sato and Nakajima, 1987 & Dichloromethane (Methylene chloride) & 9.7 & 15.7 \\
\hline Sato and Nakajima, 1987 & Diethyl ether & 14 & 4.6 \\
\hline Taneko et al., 1994 & Ethanol & 1440 & 0.08 \\
\hline Sato and Nakajima, 1987 & 2-Hexanone (Methyl n-butyl ketone) & 127 & 12.9 \\
\hline Åstrand, 1975 & Halothane & 2.3 & $\approx 60$ \\
\hline Perbellini et al., 1986 & n-Hexane & 0.8 & 130 \\
\hline Sato and Nakajima, 1987 & Methanol & 2100 & 0.03 \\
\hline Sato and Nakajima, 1987 & Methyl isobutyl ketone & 90 & 10.3 \\
\hline Sato and Nakajima, 1987 & Monochlorobenzene & 30.8 & 122.1 \\
\hline Sato and Nakajima, 1987 & Styrene & 51.9 & 105.4 \\
\hline Koizumi, 1989 & Tetrachloroethylene & 11.0 & 118.6 \\
\hline Reitz et al., 1988 & 1,1,1-Trichloroethane (Methylchloroform) & 2.5 & 103.9 \\
\hline Sato and Nakajima, 1987 & 1,1,2-Trichloroethane & 38.6 & 58.8 \\
\hline Fernández et al., 1977 & Trichloroethylene & 9 & 66.7 \\
\hline Sato and Nakajima, 1987 & Toluene & 15.6 & 94.2 \\
\hline Sato and Nakajima, 1987 & Xylenes & $26-37$ & $98.1-140$ \\
\hline
\end{tabular}

philic, with fat/blood coefficients several orders of magnitude greater than their blood/air coefficients. They will thus pass more slowly from alveolar air to blood, but once in the blood, it will be transferred readily to the fat tissues.

The distribution of solvents in the body is described by pharmacokinetic models. These models attempt to separate lungs, vessel-rich tissues, muscles, and fat tissues [Csanády et al., 1994; Perbellini et al., 1986; Sato and Nakajima, 1987]. Perbellini et al. [1986] provided an excellent model (validated among shoe manufacturers) of the accumulation of metabolites to be expected from occupational exposure to $\mathrm{n}$-hexane, when there is insufficient time for concentrations to relax to their baseline levels. The accumulation in fat tissue follows a sawtooth pattern, by which concentrations start off the workweek at a certain baseline level, increase until the end of the workshift (when they reach their maximum values), and slowly decrease during the evening and the night but never reach the previous day's minimum. Thus, concentrations in fat tissue increase until saturation, or until exposure ceases for at least 10 days [Perbellini et al., 1986]. To our knowledge, pharmacokinetic models of sol- vent metabolism incorporating the breast as a separate compartment have not been developed.

With blood flow being mostly to the blood rich organs, a large fraction of organic solvents will be taken up by the liver and the kidneys, and the remainder will be distributed to and absorbed by fatty tissues and other tissues. The liver and kidneys are active sites for the biotransformation of these xenobiotics. Depending on the detoxification mechanisms and the resulting types of by-products, some of these compounds will be excreted, but others will enter the bloodstream. Given its good vascular supply and its relatively large number of lipid cells, the breast can be an important depot for lipophilic untransformed xenobiotics and lipophilic by-products.

Once stored in surrounding fat tissues, organic solvents can migrate into the lobules and then be transported to the ductular system as a secretory product of the epithelial cells, and by simple, passive or active diffusion through cell membranes, by direct transport via inter-cellular spaces and via water-filled pores in the cell membranes [Sim and McNeil, 1992]. 
The accumulation of organic solvents in fat tissues has been documented by Engström and Bjurström [1977] who exposed 12 volunteers (six "slim" and six "obese") to methylene chloride for 1 hour while they worked at four different levels of intensity of exercise on a bicycle ergometer. Obese subjects had a higher total solvent intake, but the slim subjects had a higher rate of uptake per unit weight $(\mathrm{mg} / \mathrm{kg})$; however, the solvent was eliminated at a slower pace in obese subjects compared to leaner ones. The authors calculated that between $10 \%$ to $33 \%$ of the total solvent uptake was stored in the fat tissues (from samples taken from the buttocks) [Engström and Bjurström, 1977]. In animal experiments, the increased toxicity observed for females exposed to benzene could be related to longer retention times because of the larger volume of body fat in females [Sato et al., 1975; Sato and Nakajima, 1987]. Engström and Bjurström [1977] also reported that solvent concentrations in fat tissues probably vary according to blood perfusion, so that well perfused tissues would accumulate a higher concentration of solvents. This suggests that the cyclic increase in blood flow to the breast tissue could thus result in higher levels of solvents and their metabolites in the surrounding fat tissues.

\section{Metabolism}

Most xenobiotics undergo two types of detoxification processes occurring mostly in the liver and the kidneys: phase I processes, consisting of oxidation and reduction reactions, and phase II processes, consisting of conjugation reactions rendering them water-soluble and more easily excretable [Klaassen and Eaton, 1991]. However, the metabolism of organic solvents through the phase I processes may produce more toxic compounds (bioactivation) [Andrews and Snyder, 1991]. The oxidation reactions, mediated mostly through the cytochrome P-450 enzymatic system, produce alcohols, aldehydes or ketones, and epoxides, and the reduction reactions produce reactive free radicals. The extent and rates of biotransformation of each substance are affected by numerous factors, including age, sex, dose [Toftgård and Gustafsson, 1980], and the presence of other endogenous or exogenous chemicals that act as inducers of P-450 cytochromes [Arınç et al., 1991; Toftgård and Gustafsson, 1980] and of glutathione transferases [Bounous et al., 1991]. It has been shown that several chlorinated hydrocarbons induce microsomal enzymes [Alvares et al., 1977; Poland et al., 1970]. Because the liver and the kidneys are the main organs responsible for the P-450 system-mediated metabolic reactions, they are also the primary target organs for in situ toxicity related to highly reactive metabolites (e.g., epoxides, free radicals, alkylating agents).

Table III shows toxicologic features of P-450 biotransformation reactions for some of the most widely used aromatic and halogenated solvents, as well as a summary of the evidence of carcinogenic effects from human and animal studies. As an example, styrene undergoes oxidation through microsomal enzymes, mainly the P-450 cytochromes in the liver, and is subjected to epoxidation and hydroxylation reactions, and the resulting glycol is conjugated with $\beta$-glucuronic acid, or is oxidized. Styrene-7,8-oxide is thus formed but is detoxified very rapidly by microsomal epoxide hydrolase, another enzyme found near the P-450 complex, so that the epoxide is metabolized more rapidly than it diffuses across the cell [Csanády et al., 1994; Löf et al., 1986]. There is some evidence, however, that styrene-7,8oxide is not completely detoxified, as it has been measured in the blood of styrene exposed workers [Korn et al., 1994; Löf et al., 1986].

Halogenated solvents also undergo metabolic activation by the cytochrome P-450 system. For example, carbon tetrachloride is thought to be cleaved to form a trichloromethyl radical that reacts with unsaturated fatty acids to produce an epoxide, which is particularly reactive when there is asymmetrical chlorine substitution [Toftgård and Gustafsson, 1980].

For some xenobiotics, it has been shown that a significant fraction can be metabolized outside the liver, e.g., up to $25 \%$ for trichloroethylene in dogs [Hobara et al., 1986]. Mammary glands are not a major site of metabolic activity, but they display cytochrome P-450 mediated [Eldridge et al., 1992; Gould, 1980; Maack et al., 1986] and glutathione-Stransferase mediated [Batist et al., 1991; Schecter et al., 1992] metabolic activity originating from different cell types [Gould, 1982]. Breast tissue, however, lacks certain enzymes (e.g., hydroxylases) capable of detoxifying hydrocarbons, so that they may accumulate unchanged [Dao, 1969; Dao and Varela, 1966]. There are no estimates of the extent to which organic solvents are bioactivated within the breast or whether metabolites produced by the liver and other organs find their way to breast tissue. We are also not aware of any studies investigating the presence of epoxides in human breast fluids, except for cholesterol epoxides [Petrakis et al., 1981].

Epoxides and free radicals are electrophilic and bind covalently to different proteins, thereby providing a potential mechanism for organ-specific toxicity, mutagenicity, and carcinogenicity. Some examples include covalent binding of: benzene metabolites to proteins in the bone marrow of exposed animals (benzene is a bone marrow depressant); carbon tetrachloride, a potent hepatotoxic agent, to macromolecules in the liver cells of exposed animals; and oxidized metabolites of vinyl chloride, a recognized hepatic carcinogen, to nucleic acids in the liver of exposed animals [Andrews and Snyder, 1991].

Another possible pathway for producing detrimental effects could be through estrogenic properties of some organic solvents or their interaction with estrogenic substances, thereby increasing cellular proliferation and geno- 
TABUE III. Toxicological Profile of Some Organic Solvents Following Inhalation ${ }^{a}$

\begin{tabular}{|c|c|c|c|c|c|c|c|c|}
\hline \multirow{2}{*}{$\begin{array}{l}\text { Organic } \\
\text { solvent } \\
\text { (reference) }\end{array}$} & \multicolumn{2}{|c|}{ Humenstudies } & \multicolumn{2}{|c|}{ Animal studies } & \multirow[b]{2}{*}{$\begin{array}{l}\text { IARC } \\
\text { class* }\end{array}$} & \multirow[b]{2}{*}{$\begin{array}{l}\text { Short-term } \\
\text { assays }\end{array}$} & \multirow[b]{2}{*}{$\begin{array}{l}\text { Absorption and } \\
\text { Cfistribution }\end{array}$} & \multirow[b]{2}{*}{$\begin{array}{l}\text { Metabolism } \\
\text { and excretion }\end{array}$} \\
\hline & $\begin{array}{l}\text { Cancer } \\
\text { site }\end{array}$ & $\begin{array}{l}\text { Jold } \\
\text { inchstry }\end{array}$ & $\begin{array}{l}\text { Cancer } \\
\text { site }\end{array}$ & Species & & & & \\
\hline $\begin{array}{l}\text { Acetone } \\
\text { ATSDR** 1992g }\end{array}$ & NA & NA & NA & NA & nC & Mostly negative results & $\begin{array}{l}\text { Hoghly water soluble } \\
\text { Lung absorption } \approx 75-80 \% \\
\text { No significart differences between } \\
\text { sereses }\end{array}$ & 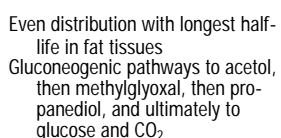 \\
\hline $\begin{array}{l}\text { Automotive gasoline } \\
\text { ATSDR, 1993d }\end{array}$ & $\begin{array}{l}\text { Stomach } \\
\text { Kidney, possibly other sites }\end{array}$ & $\begin{array}{l}\text { Male workers exposed to gasoline } \\
\text { Male workers exposed to hydro- } \\
\text { carbons }\end{array}$ & $\begin{array}{l}\text { Kidney } \\
\text { Liver }\end{array}$ & $\begin{array}{l}\text { Rat } \\
\text { Female mice }\end{array}$ & croup $2 B$ & $\begin{array}{l}\uparrow \text { micronucle in Iymphocyles }(\mapsto) \\
\text { Mostly negative studies (A) }\end{array}$ & $\begin{array}{l}\text { Pattems of absonption and distri- } \\
\text { bution vary with proportion of } \\
\text { indinidual corponenents } \\
\text { Accumiation of some hydrocar- } \\
\text { bons in fat tissues }\end{array}$ & Vary with individual components \\
\hline $\begin{array}{l}\text { Benzene } \\
\text { ATSDR, 1989; NIP,*** 1986b }\end{array}$ & Hematopoietic system & Rubber workers, cherrical workers & $\begin{array}{l}\text { Marmary gland } \\
\text { Skin, oral cavity, etc. } \\
\text { Marmmary gland (ingestion) }\end{array}$ & $\begin{array}{l}\text { Rat } \\
\text { Mouse and rat } \\
\text { Mouse }\end{array}$ & croup 1 & $\begin{array}{l}\text { Chromosomal aberrations (Hand } \\
\text { A) } \\
\text { ifCs and micronudei DNA } \\
\text { binding }\end{array}$ & $\begin{array}{l}\text { Lung absoption } \approx 50 \% \\
\text { Complete equilibrium within a few } \\
\text { days } \\
\text { Amount of body fat influences } \\
\text { towirktiofifc }\end{array}$ & $\begin{array}{l}\text { Epoxide intem mediate } \\
\text { Hydroxylation, mostly to phenols, } \\
\text { hydroquinones and catechol } \\
\approx 64 \% \text { metabolised }\end{array}$ \\
\hline $\begin{array}{l}\text { Bromoform } \\
\text { ATSDR, 1990a }\end{array}$ & NA & NA & Large intestine (ingestion) & Rat & Group 3 & $\begin{array}{l}\uparrow \text { SCE in mouse bone marrow cells } \\
\text { Inconsistent findings }\end{array}$ & 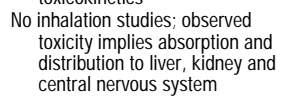 & 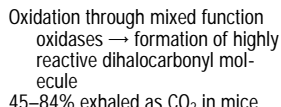 \\
\hline $\begin{array}{l}\text { 2-Butanone (methy } \\
\text { ethy ketone) } \\
\text { ATSDR, 1992a }\end{array}$ & No excess cancer deaths & $\begin{array}{l}\text { Exposed workers in dewaxing } \\
\text { plant }\end{array}$ & NA & NA & NC & Mostly negative results & $\begin{array}{l}\text { Lung uptake } \approx 41-56 \% \\
\text { No accumbulation in arnt tissue } \\
\text { (blood/tissue partition coeffi- } \\
\text { cients all } \approx 1 \text { ) }\end{array}$ & $\begin{array}{l}45-84 \% \text { exhaled as } \mathrm{CO}_{2} \text { in mice } \\
\text { Metabolism to 2-buttand and ather } \\
\text { hydroxy devivatives } \\
\approx 20-40 \% \text { exthaled unchanged }\end{array}$ \\
\hline $\begin{array}{l}\text { Carbon disulfide } \\
\text { ATSDR, 1993h }\end{array}$ & Possibly leukenia & Rubber workers & NA & NA & nC & Equivocal results & $\begin{array}{l}\text { Lung retention } \approx 40-80 \% \\
\text { Fat accumlation }\end{array}$ & 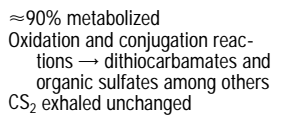 \\
\hline $\begin{array}{l}\text { Carbon terachloride } \\
\text { ATSDR, 1992C }\end{array}$ & Possibly liver & Exposed workers & $\begin{array}{l}\text { Liver (ingestion) } \\
\text { No inhalation studies }\end{array}$ & Rat, hamster, mouse & Group $2 B$ & DNA binding & $\begin{array}{l}\text { Lung absorntion } \approx 60 \% \\
\text { Accumulation in lipic-rich tissues }\end{array}$ & 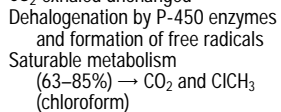 \\
\hline $\begin{array}{l}\text { Cllorobenzene } \\
\text { ATSDR, 1990b }\end{array}$ & NA & NA & Liver and kidhey (ingestion) & Rat and mouse & NC & Equivocal results & $\begin{array}{l}\text { Absonption } \approx 38-45 \% \\
\text { Distribition proportional to con- } \\
\text { centration } \\
\text { Fat accumulation }\end{array}$ & $\begin{array}{l}\text { Oxidation to } 4 \text { - chlorocotectechol and } \\
\text { coniugation to p-chlorophenol- } \\
\text { mercapturic acid (with epoxide } \\
\text { formation) }\end{array}$ \\
\hline $\begin{array}{l}\text { Clloromethane } \\
\text { ATSDR, 1990C }\end{array}$ & No excess deaths & Buty rubber plant (males) & Kidney (1000 porr/24 months) & Mouse & croup 3 & $\begin{array}{l}\text { Mutagenic for S.t } \\
\text { Mutageric and effects on SCEs in } \\
\text { mammalian cells in vivo }\end{array}$ & $\begin{array}{l}\text { Rapic absorption and distribution } \\
\text { Concept of fast and slow metabo- } \\
\text { lizers }\end{array}$ & $\begin{array}{l}\text { Coniugated as S-methylysteine } \\
\text { Consistent with 2-compartment } \\
\text { mode }\end{array}$ \\
\hline $\begin{array}{l}\text { 1,2-Dibromoethane } \\
\text { ATSDR, 1992b; NIP, 1992a }\end{array}$ & No excess deaths & $\begin{array}{l}\text { Chemical workers (studies with } \\
\text { limitations) }\end{array}$ & $\begin{array}{l}\text { Marmary gland } \\
\text { Hemangiosarcomes of circulationy } \\
\text { system etc. }\end{array}$ & Rat and mouse & Group 2A & $\begin{array}{l}\text { Mutageric for S.t and D.m; DNA } \\
\text { binding } \\
\text { Crromosomal aber. + SCES }\end{array}$ & $\begin{array}{l}\text { Absopotion and distribution poorly } \\
\text { documented in humars and } \\
\text { animals }\end{array}$ & 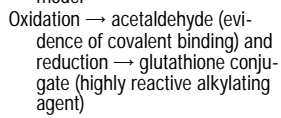 \\
\hline $\begin{array}{l}\text { 1,1-Dichloroethane } \\
\text { ATSDR, 1990d }\end{array}$ & NA & NA & Marmary gland (ingestion) & Rat & NC & NA & $\begin{array}{l}\text { Previously used as anesthetic } \\
\text { agent: Rapid absorption and } \\
\text { distribution } \\
\text { Fat accumulation }\end{array}$ & 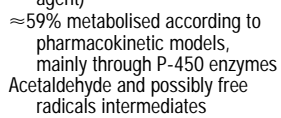 \\
\hline $\begin{array}{l}\text { 1,2-Dichloroethane } \\
\text { (ethylene dichloride) } \\
\text { ATSDR, 1992h }\end{array}$ & Not clear & Petrocherical workers & Marmary gland, etc. (ingestion) & Rat & Group 2B & $\begin{array}{l}\text { DNA binding and positive effects } \\
\text { on SCE }\end{array}$ & $\begin{array}{l}\text { Rapid absonption and fat accumt } \\
\text { Iation } \\
\text { Rapid distribution (few hours) }\end{array}$ & $\begin{array}{l}\text { Saturable metabolism mainly } \\
\text { trrough glutathione-mediated } \\
\text { conjugation } \\
\text { Chlorohydrin and aceteldehyde } \\
\text { inthemediates } \\
\text { Probably }>80 \% \text { metabolised }\end{array}$ \\
\hline $\begin{array}{l}\text { Dimethy-formanide } \\
\text { NIP, 1992b }\end{array}$ & Testicular and buccal cavity & $\begin{array}{l}\text { Aircraft maintenance workers and } \\
\text { leather tanners }\end{array}$ & NA & NA & Group $2 B$ & Mostly negative results & Skin absorption can be important & 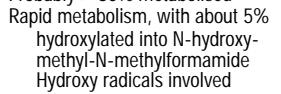 \\
\hline
\end{tabular}


TABLE III. Toxicological Profile of Some Organic Solvents Following Inhalationa (continued)

\begin{tabular}{|c|c|c|c|c|c|c|c|c|}
\hline \multirow{2}{*}{$\begin{array}{l}\text { Organic } \\
\text { solvent } \\
\text { (refierence) }\end{array}$} & \multicolumn{2}{|c|}{ Humenstudies } & \multicolumn{2}{|c|}{ Animal studies } & \multirow[b]{2}{*}{$\begin{array}{l}\text { IARC } \\
\text { class* }\end{array}$} & \multirow[b]{2}{*}{$\begin{array}{l}\text { Short-term } \\
\text { assays }\end{array}$} & \multirow[b]{2}{*}{$\begin{array}{l}\text { Absonption and } \\
\text { cistribution }\end{array}$} & \multirow[b]{2}{*}{$\begin{array}{l}\text { Metabolism } \\
\text { andexcretion }\end{array}$} \\
\hline & $\begin{array}{l}\text { Cancer } \\
\text { site }\end{array}$ & $\begin{array}{l}\text { Joby } \\
\text { inclustry }\end{array}$ & $\begin{array}{l}\text { Cancer } \\
\text { site }\end{array}$ & Species & & & & \\
\hline $\begin{array}{l}\text { Ethylbervene } \\
\text { ATSDR, 1990e }\end{array}$ & No cancer cases & "Chronically exposed" workers & $\begin{array}{l}\text { ? Total malignant tumors (inges- } \\
\text { tion) }\end{array}$ & Rat & NC & Mostly negative results & $\begin{array}{l}\text { Lung retention 49-64\% } \\
\text { Adipose tissue retention after } \\
\text { 2-hour exposure } \approx 5 \%\end{array}$ & $\begin{array}{l}\text { Hydroxylation and glucuronide } \\
\text { conjugation } \\
\text { Major metabolites: mandelic and }\end{array}$ \\
\hline $\begin{array}{l}\text { Ethylene glycol } \\
\text { ATSDR, 1993e }\end{array}$ & No excess renal cancer deaths & $\begin{array}{l}\text { Cherical workers (small sample } \\
\text { size) }\end{array}$ & Lack of effect (ingestion studies) & Mouse and rat & nC & Mostly negative results & $\begin{array}{l}\text { No available information on inhala } \\
\text { tion upptake } \\
\text { Rapid absorption and distribution } \\
\text { after ingestion }\end{array}$ & $\begin{array}{l}\text { Nephro and neuro-toxicity } \\
\text { Metabolismto } \\
\text { aldethde } \rightarrow \text { glyoxylic and } \\
\text { oxdic acids }\end{array}$ \\
\hline $\begin{array}{l}\text { Fue oils (kerosenene) } \\
\text { ATSDR, } 1993 \mathrm{f}\end{array}$ & No excess cancer & $\begin{array}{l}\text { "Chronically exposed" male and } \\
\text { fermale workers }\end{array}$ & Skin and liver & Mouse & nC & Incondusive studies & $\begin{array}{l}\text { Pattems of absonption and distri- } \\
\text { bution vary with proportion of } \\
\text { individual components }\end{array}$ & Vary with individual components \\
\hline $\begin{array}{l}\text { 2-Hexanone (methy buty ketone) } \\
\text { ATSDR, } 1992 \mathrm{~d}\end{array}$ & NA & NA & NA & NA & nC & NA & $\begin{array}{l}\text { Lung absontion } \approx 75-92 \% \\
\text { No available studies on nistribution }\end{array}$ & $\begin{array}{l}\text { Reduction to 2-hexanol and oxicta } \\
\text { tion to 2,5-hexanedione } \\
\text { (responsible for well-known } \\
\text { neurotoxic effects) }\end{array}$ \\
\hline $\begin{array}{l}\text { Jet fueds J P-4 and J P-7 } \\
\text { ATSDR, 1993g }\end{array}$ & NA & NA & Incondusive evidence & Mouse and rat & NC & Incondusive studies & $\begin{array}{l}\text { Evidence of absontion, but no } \\
\text { hard data }\end{array}$ & No data \\
\hline $\begin{array}{l}\text { Methylene chloride (dichloro- } \\
\text { methane) } \\
\text { ATSDR 1991a; NIP, 1986a }\end{array}$ & No excess deaths & $\begin{array}{l}\text { Workers in photo development } \\
\text { plant }\end{array}$ & $\begin{array}{l}\text { Marmary gland (berign) } \\
\text { Liver and lung }\end{array}$ & Mouse and rat & Group 2B & $\begin{array}{l}\text { Mutagenic for S.t. } \\
\text { Chromosomal aberrations (A) }\end{array}$ & $\begin{array}{l}\text { Lung absomption } \approx 70-75 \% \\
\text { Amourt of body fat influences } \\
\text { toxicokinetics }\end{array}$ & $\begin{array}{l}\text { Mixed function oxidase } \\
\text { pathway } \rightarrow \text { cOand gluta- } \\
\text { thione transferase } \\
\text { pathway } \rightarrow \mathrm{CO}_{2} \\
\text { Possible free radicals intermedi- }\end{array}$ \\
\hline $\begin{array}{l}\text { Styrene } \\
\text { ATSDR, 1992e }\end{array}$ & Leukeria, Iymphoma(?) & $\begin{array}{l}\text { Workers in styrene- based products } \\
\text { (Problem of multiple expo- } \\
\text { sures) }\end{array}$ & $\begin{array}{l}\text { Possibly mammary gland } \\
\text { Stomach (ingestion of styrene } \\
\text { oxide) }\end{array}$ & $\begin{array}{l}\text { Rat } \\
\text { Mouse and rat }\end{array}$ & Group $2 B$ & $\begin{array}{l}\text { Crromosomal aberrations }(H) ; \\
\text { increase in micronuclei }(H) \\
\text { Gendotoxic metabolites }(A)\end{array}$ & $\begin{array}{l}\text { Lung retention } \approx 60-70 \% \\
\text { Rapid accumulation in fat tissues } \\
\qquad(\mapsto)\end{array}$ & 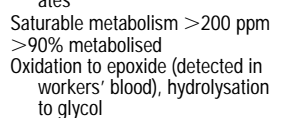 \\
\hline $\begin{array}{l}\text { Tetrachloroethylene } \\
\text { ATSDR, 1993b; NTP, } 1986 c\end{array}$ & $\begin{array}{l}\text { Doubtru: liver, kichey, bladder, } \\
\text { cenix? }\end{array}$ & $\begin{array}{l}\text { Dry cleaning workers } \\
\text { Exposed craftsmen }\end{array}$ & Liver, lekenria and kidney & Mouse and rat & Group 2A & $\begin{array}{l}\text { Negative findings for the solvent } \\
\text { Gutathione conjugated metabo- } \\
\text { lites mutageric }\end{array}$ & $\begin{array}{l}\text { Pulmonary uptake } \propto \text { ventilation } \\
\text { rate, duration of exposure and } \\
\text { concentration in the inspired } \\
\text { air }\end{array}$ & $\begin{array}{l}\text { Majior metabolites: mandelic and } \\
\text { phentiglyoxylic acids } \\
\text { Saturable metabolism } \approx 10 \% \\
\text { metabolised) } \rightarrow \text { trichloroacetic } \\
\text { acid, some thioethers? } \\
\text { Epoxide intermediate }\end{array}$ \\
\hline $\begin{array}{l}\text { Toluene } \\
\text { Andrews and Sryder, 1991; Tott- } \\
\text { grd and Qustafsson, } 1980\end{array}$ & NA & NA & NA & NA & Group 3 & Equivocal results & $\begin{array}{l}\text { Fat accumlation }(A) \\
\text { Lung absontion } \approx 53 \% \\
\text { Fat accumlation }\end{array}$ & $\begin{array}{l}\approx 80 \% \text { metabolised (20\% exhaled } \\
\text { unchanged) } \\
\text { Hychroxlation and } \\
\text { oxidation } \rightarrow \text { berzoic acid and } \\
\text { conjuggation } \rightarrow \text { hippuric acid }\end{array}$ \\
\hline $\begin{array}{l}\text { 1,1,1-Trichloroethane } \\
\text { ATSDR, 1993i }\end{array}$ & NA & NA & Negative study & Mouse and rat & Group 3 & Equivocal results & $\begin{array}{l}\text { Lung retention } \approx 25-30 \% \\
\text { increasing with workload } \\
\text { Rapid distribution fromblood, pri- } \\
\text { marily to fat and liver }\end{array}$ & $\begin{array}{l}<10 \% \text { metabolised mainly to } \\
\text { trichloroacciscic acid and trichlo- } \\
\text { roethand } \\
\text { Freeeradical intermediate }\end{array}$ \\
\hline $\begin{array}{l}\text { Trichloroethylene } \\
\text { ATSDR, 1993c; NTP, } 1988\end{array}$ & Bladder, Iymphomes & Exposed men & $\begin{array}{l}\text { Testicles, kichey, lung, etc. } \\
\text { Liver, kichey (ingestion) }\end{array}$ & $\begin{array}{l}\text { Mouse and rat } \\
\text { Rat }\end{array}$ & Group 2A & $\begin{array}{l}\text { Castogenic effects }(H) \\
\text { Mutagenic to mouse lymphoma } \\
\text { cells }\end{array}$ & $\begin{array}{l}\text { Lung retention } \approx 37-64 \% \text {, varies } \\
\text { with concentration, duration of } \\
\text { exposure and alveolar ventila } \\
\text { tion rate } \\
\text { Accumulation in fat and blood }\end{array}$ & 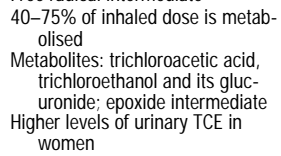 \\
\hline $\begin{array}{l}\text { Trichloromethane (chloroform) } \\
\text { ATSDR, 1993a }\end{array}$ & Colon and bladder & $\begin{array}{l}\text { Population exposed to chlorinated } \\
\text { drinking water (ingestion) }\end{array}$ & Liver, kidney & Mouse and rat & Goup 2B & Equivocal results & $\begin{array}{l}\text { Lung retention documented by } \\
\text { anesthetic effects } \\
\text { Accumulation in fat and brain }\end{array}$ & $\begin{array}{l}\approx 50 \% \text { excreted } \mathrm{as} \mathrm{CO}_{2} \\
\text { Bioactivation to phosgene, then } \\
\text { bound to glututhionione } \\
\approx 17 \% \text { extaled unchanged }\end{array}$ \\
\hline $\begin{array}{l}\text { 1,2,3-Trichloropropane } \\
\text { ATSDR, } 1992 \mathrm{f}\end{array}$ & NA & NA & $\begin{array}{l}\text { Marmary gland } \\
\text { Forestornach and others sites } \\
\text { (gavage) }\end{array}$ & $\begin{array}{l}\text { Rat } \\
\text { Mouse and rat }\end{array}$ & Group 2A & Mutagenic to S.t. & $\begin{array}{l}\text { No studies available on absonption } \\
\text { vai inhalation } \\
\text { Oral exposure: } 80 \% \text { absonption } \\
\text { Rapid distribution to vessel- } \\
\text { rich tissues and fat }\end{array}$ & 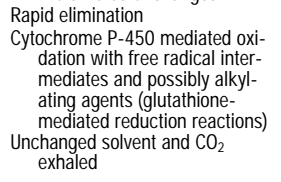 \\
\hline
\end{tabular}



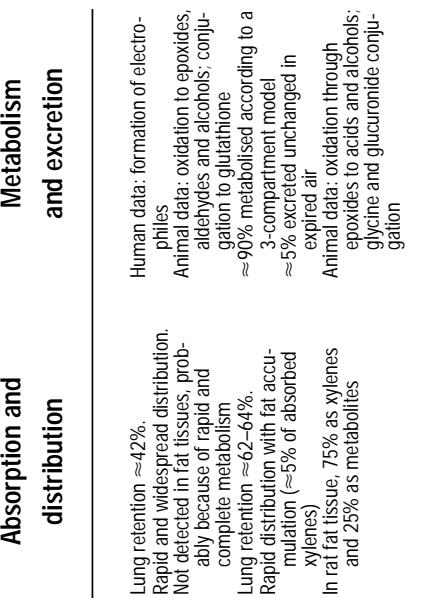

toxic effects simultaneously [Davis et al., 1993]. There are a few anecdotal reports of the estrogenic properties of phenols, organic solvents used to synthesize plastics, leached from laboratory ware [Krishnan et al., 1993; Soto et al., 1991]. Although one cannot infer estrogenic activity solely from chemical structure, it is reasonable to believe that other organic solvents display some estrogenic activity [Soto et al., 1991].

\section{Carcinogenicity of Organic Solvents}

\section{Short-term studies}

Short-term assays can be useful in detecting potential carcinogens through the investigation of genotoxic effects of pure substances in microbial, mammalian, or human cells. Genotoxic effects are not necessarily precursors of carcinogenic activity, but they can be regarded as indicators of possible carcinogenic effects. Few assays have been carried out using metabolites, which are often the biologically active molecules. Short-term assays carried out in vivo in mammals may be a promising approach [Bridges, 1986].

Several solvents have exhibited certain cytotoxic effects in short-term studies (see Table III). Chromosomal aberrations in peripheral blood lymphocytes of exposed workers have been found for exposure to benzene, methylene chloride, and styrene [Pelkonen and Raunio, 1995; Agency for Toxic Substances and Disease Registry, 1991a, 1992e]; increased incidence of sister chromatid exchanges in mammalian cells were observed for chloromethane and 1,2dichloroethane [Agency for Toxic Substances and Disease Registry, 1990c, 1992h]; mutagenicity in Ames tests was indicated for chloromethane, 1,2-dibromoethane, methylene chloride, 1,2,3-trichloropropane, and vinyl chloride [Agency for Toxic Substances and Disease Registry, 1990c, 1991a,b, 1992b,f]; and DNA binding to microsomal lipids, proteins, and other cellular macromolecules has been reported for carbon tetrachloride, 1,2-dichloroethane and vinyl chloride [Agency for Toxic Substances and Disease Registry, 1991b, 1992c,h].

\section{Long-term animal studies}

Carcinogenicity experiments in laboratory animals have led to the identification of a number of organic solvents as potential human breast carcinogens, including benzene, 1,2-dibromoethane, 1,1-dichloroethane, 1,2-dichloroethane, methylene chloride, styrene, 1,2,3-trichloropropane, vinyl chloride [Agency for Toxic Substances and Disease Registry, 1989, 1990d, 1991a,b, 1992b,e,f,h; National Toxicology Program, 1986a,b, 1992a]. Results from these studies may not necessarily be generalizable to humans because, for a given route of absorption, major differences exist between 
species in uptake, distribution, and metabolism [Klaassen and Eaton, 1991]. For example, after exposure to styrene, much higher quantities of styrene oxide are produced by mice than by rats or humans. As well, humans have the highest capacity of the three species to metabolize styrene oxide [Agency for Toxic Substances and Disease Registry, 1992e]. In addition, most animal studies are based on single exposures rather than on mixtures. Human exposure is invariably to complex mixtures and interactions between different solvents may inhibit or potentiate known effects of individual solvents [Andrews and Snyder, 1991].

\section{Epidemiology}

The effects of exposure to organic solvents and the risk of female breast cancer have been reported in only a handful of occupational studies [Goldberg and Labrèche, 1996]. We will summarize here a few cohort and case-control studies that focused on solvent-exposed workers (Table IV).

Laundry and dry cleaning workers (exposed at varying degrees and at different time periods to stoddard solvent, carbon tetrachloride, perchloroethylene, trichloroethylene, and fluorocarbons [Blair et al., 1990; Brown and Kaplan, 1987; Ruder et al., 1994] were investigated in two mortality cohort studies and no excess risks were observed. Mortality rates among aircraft maintenance workers exposed to trichloroethylene were not greater than expected, although excess risks were observed, for exposure to isopropyl alcohol and methylene chloride [Spirtas et al., 1991]. Axelson and coworkers [1978, 1994] also investigated cancer incidence and mortality in trichloroethylene exposed workers, but no risk estimates were provided for cancer of the breast, and one must assume that very few cases were observed. An excess risk for breast cancer incidence was observed among women employed for 5 years and more in coiling and wire drawing [Shannon et al., 1988] in the manufacturing of lamps, in which methylene chloride and trichloroethylene may have been used. A cohort study of female shoe manufacturers [Paci et al., 1989], who were exposed to a number of substances including organic solvents (benzene, toluene, hexane, methyl ethyl ketone, acetone, and solventbased adhesives) observed no association for breast cancer mortality, but statistical power was very low. A cohort study of garment workers exposed to formaldehyde was also negative [Stayner et al., 1985, 1988]. Mikoczy and coworkers [1994] conducted a cohort study of leather tannery workers exposed to a number of compounds, including benzene and other chlorinated solvents, and found incidence rates to be between $30 \%$ and $50 \%$ above expected. A case-control analysis of a small cohort of polyvinylchloride workers showed a nonsignificantly elevated risk of death from breast cancer [Chiazze et al., 1977, 1980]. No associations were observed for mortality among styrene-exposed workers [Kogevinas et al., 1994; Wong, 1990; Wong et al., 1994], or for incidence among workers exposed to halogenated solvents [Anttila et al., 1995]; the latter study constituted its cohort from a database of workers monitored for halogenated solvent exposure between 1965 and 1982, and followed-up for cancer incidence between 1967 and 1992. Finally, a case-control study on the effect of hormone replacement therapy and breast cancer found an increased risk for the group of painters, sculptors, and printmakers [Habel et al., 1995]. Studies of organic solvents may, however, be beset with health-related, differential selection into and out of work arising from early-onset toxic effects (e.g., dermatitis, hepatic and renal toxicity, central nervous system depression, peripheral neuropathy) [Andrews and Snyder, 1991]. Thus, a selection bias may occur in cohort studies if susceptible or sensitive workers are at higher risk for developing breast cancer and are more likely to leave exposed jobs early (less highly exposed than insensitive persons).

Important limitations of these cohort and case-control studies restrict their usefulness: 1) only one was designed specifically to study breast cancer, information on major confounders was missing, and separate analyses were not provided according to menopausal status; 2) most of these studies investigated cancer mortality, whereas incidence figures are more appropriate given the relatively long survival rates for breast cancer; 3) statistical power was low as women constituted a small proportion of the work force in many studies; 4) most studies relied on broad occupational groupings as a proxy for exposure assessment. In summary, the available epidemiologic data are inconclusive regarding the relation between organic solvents and female breast cancer risk.

\section{SUMMARY AND CONCLUSIONS}

Our theory is based on three elements: 1) the toxicokinetic distribution of lipophilic solvents in the body favoring accumulation in and around breast tissue; 2) a theory of chemical deposition and retention in the breast, previously suggested by Petrakis and coworkers [Petrakis, 1977b, 1986; Petrakis et al., 1982]; and 3) carcinogenic properties of certain organic solvents and their metabolites.

While there are scant epidemiologic data related to organic solvent exposures and breast cancer, other lines of evidence support the hypothesis. First, it is well known that some organic solvents will accumulate in fat tissue after typical occupational exposures. Second, a number of organic solvents have been detected in human milk, often in higher concentrations than in the blood. Third, the observation that a high proportion of breast cancers are ductular is consistent with the stagnation model of Petrakis. Fourth, nipple aspirates have been shown to be mutagenic in some women. And fifth, a few organic solvents (benzene, styrene, vinyl chlo- 


\begin{tabular}{|c|c|c|c|c|c|c|c|}
\hline Refierence & $\begin{array}{l}\text { Type } \\
\text { of study }\end{array}$ & $\begin{array}{l}\text { Occupetion } \\
\text { or industry }\end{array}$ & $\begin{array}{l}\text { Organic } \\
\text { solvents }\end{array}$ & $\begin{array}{l}\text { Total } \\
\text { number } \\
\text { of women }\end{array}$ & $\begin{array}{l}\text { Number } \\
\text { of breast } \\
\text { cancers }\end{array}$ & Risk & $\begin{array}{l}\mathbf{9 5 \%} \% \\
\text { Confidence } \\
\text { intenvel or } \\
\text { Pvalue }\end{array}$ \\
\hline Chiazze et al., 1977, 1980 & Cohort (mortality) & Poly vinylchloride fabricators & Vinyl chloride & $N R^{*}$ & 44 & $\mathrm{PMR}=1.8$ & $P>0.05$ \\
\hline Axelson et al., 1978, 1994 & Cohort (mortality) & $\begin{array}{l}\text { Trichloroethylene exposed } \\
\text { workers }\end{array}$ & Trichloroethylene & 249 & $\begin{array}{c}\mathrm{NR} \\
(<11)\end{array}$ & NR & - \\
\hline Stayner et al., 1985, 1988 & Cohort (mortality) & Garment industry & Formaldehyde & 9,022 & 33 & $\mathrm{SMR}=0.7$ & $0.5-1.0$ \\
\hline \multirow[t]{2}{*}{ Ruder et al., 1994} & Cohort (mortality) & Dry cleaning & $\begin{array}{l}\text {-Entire cohort } \\
\text {-Tetrachloroethylene + other } \\
\text { solvents }\end{array}$ & $\begin{array}{r}1,109 \\
695\end{array}$ & $\begin{array}{l}19 \\
13\end{array}$ & $\begin{array}{l}\mathrm{SMR}=1.1 \\
\mathrm{SMR}=1.1\end{array}$ & $\begin{array}{l}0.7-1.7 \\
0.6-1.9\end{array}$ \\
\hline & & & -Tetrachloroethylene & 414 & 6 & $\mathrm{SMR}=1.0$ & $0.4-2.2$ \\
\hline \multirow[t]{2}{*}{ Sharnon et al., 1988} & Cohort (incidence) & $\begin{array}{l}\text { Lamp manufacturing } \\
\text {-Total cohort in coiling/wire } \\
\text { drawing }\end{array}$ & $\begin{array}{l}\text { Methylene chloride, trichlo- } \\
\text { roethylene }\end{array}$ & $\begin{array}{r}1,044 \\
203\end{array}$ & $\begin{array}{r}21 \\
8\end{array}$ & $\begin{array}{l}\mathrm{NR} \\
\mathrm{SMbR}=2.0\end{array}$ & $\begin{array}{c}\mathrm{NR} \\
0.9-4.0\end{array}$ \\
\hline & & $\begin{array}{c}-\geq 5 \text { years work, } \geq 15 \\
\text { years latency }\end{array}$ & & NR & 5 & $\mathrm{SMbR}=3.2$ & $1.1-7.5$ \\
\hline Paci et al., 1989 & Cohort (mortality) & Shoe manufacturing & Benzene and other solvents & 1,005 & 4 & $\mathrm{SMR}=0.9$ & $0.2-2.3$ \\
\hline Blair et al., 1990 & Cohort (mortality) & Dry deaners & $\begin{array}{l}\text { Tetrachloroethylene and } \\
\text { other solvents }\end{array}$ & 4,046 & 36 & $\mathrm{SMR}=1.0$ & $0.7-1.4$ \\
\hline Wong et al., 1990, 1994 & Cohort (mortality) & $\begin{array}{l}\text { Reinforced plastics and } \\
\text { composites industry }\end{array}$ & Styrene & 3,868 & 14 & $\mathrm{SMR}=0.6$ & $0.3-1.1$ \\
\hline \multirow[t]{4}{*}{ Spirtas et al., 1991} & Cohort (mortality) & Aircraft maintenance & -Mixed solvents & 3,138 & 30 & $\mathrm{SMR}=0.7$ & $0.5-1.0$ \\
\hline & & & -Trichloroethylene & & 9 & $\mathrm{SMR}=0.8$ & $0.4-1.5$ \\
\hline & & & -Isopropyl alcohol & & $\mathrm{NR}$ & $\mathrm{SMR}=3.1$ & $1.3-6.4$ \\
\hline & & & -Methylene chloride & & 3 & NR & $\chi^{2}=6.2, P=0.01$ \\
\hline Kogevinas et al., 1994 & Cohort (mortality) & Styrene exposed workers & Styrene & 6,128 & 13 & $\mathrm{SMR}=0.5$ & $0.3-0.9$ \\
\hline \multirow[t]{2}{*}{ Mikoczy et al., 1994} & Cohort (incidence) & $\begin{array}{l}\text { Leather tanning: No latency } \\
\text { period }\end{array}$ & $\begin{array}{l}\text { Berzene and other chlori- } \\
\text { nated solvents }\end{array}$ & 482 & 20 & $\mathrm{SIR}=1.3$ & $0.8-2.0$ \\
\hline & & Latency $\geq 20$ years & & NR & 19 & $\mathrm{SIR}=1.5$ & $0.9-2.3$ \\
\hline Anttila et al., 1995 & Cohort (incidence) & $\begin{array}{l}\text { Workers exposed to haloge } \\
\text { nated solvents }\end{array}$ & $\begin{array}{l}\text { Trichloroethylene, tetrachlo- } \\
\text { roethylene, 1,1,1-trichlo- } \\
\text { roethane }\end{array}$ & 1,924 & 34 & $\mathrm{SIR}=0.9$ & $0.6-1.2$ \\
\hline Habel et al., 1995 & Case control (incidence) & $\begin{array}{l}\text { Painters, sculpters, print- } \\
\text { makers }\end{array}$ & Various solvents & 537 cases and 487 controls & 5 cases and 3 controls & $\mathrm{RR}=1.7$ & $0.4-7.4$ \\
\hline
\end{tabular}


ride, 1,2-dibromoethane, 1,1-dichloroethane, 1,2,3-trichloropropane), previously shown to be biotransformed to electrophilic metabolites (epoxides, free radicals, alkylating agents), have been found to cause mammary gland cancers in experiments on rodents.

Organic solvents could then act directly in carcinogenesis according to the following patterns: 1) intact solvent molecules reach the breast epithelium where they are bioactivated into electrophilic metabolites that cannot be detoxified effectively because of the reduced activity of the necessary enzymes in breast cells. Because of the unique physiology of mammary glands, the solvents and/or their metabolites accumulate in the milk ducts, long enough to exert detrimental effects locally. 2) A proportion of electrophilic metabolites produced in the liver, kidneys, and other detoxifying organs escape detoxification and migrate to the breast cells, and accumulate in the milk ducts where they exert toxic effects in situ. 3) Some unknown interaction between these two patterns and estrogenic effects of endogenous and, possibly, exogenous substances.

In view of the fact that breast cancer incidence is increasing with time, and that the known risk factors can explain only part of the increase, new areas of breast cancer research are warranted. Occupational exposure to organic solvents is one possible and interesting research area. Toxicological and biochemical studies could elucidate the distribution and metabolism of organic solvents in the breast parenchyma, and identify the solvents that display estrogenic properties. Cohort and case-control studies would be invaluable in testing these hypotheses. One difficulty is the large number of organic solvents in use today. We do not expect effects to be uniform across substances, so a judicious choice is warranted by focusing on, for example, organic solvents shown to be mammary carcinogens in animal experiments (e.g., benzene, styrene, vinyl chloride, 1,2dibromoethane, 1,1-dichloroethane and 1,2,3-trichloropropane). Another approach is to carry out a population-based case-control study that can be used to investigate many exposures simultaneously. Such a study requires detailed occupational histories of subjects and a method for translating these histories into exposures to specific substances. State-of-the-art methods, such as those developed by Siemiatycki et al. [1981], Gerin et al. [1985], and others [Stewart and Stewart, 1994a,b] can be used for this purpose. Of critical importance to the statistical power of the study is the prevalence of occupational exposure, which we have estimated to be between 4 and $17 \%$ among all women. Such a study is indeed feasible and we are currently carrying out a case-control study of postmenopausal breast cancer in Montreal.

\section{REFERENCES}

Agency for Toxic Substances and Disease Registry (1989): “Toxicological Profile for Benzene." Atlanta, GA: U.S. Department of Health and Human Services, ATSDR. TP-88/03.
Agency for Toxic Substances and Disease Registry (1990a): “Toxicological Profile for Bromoform and Chlorodibromomethane." Atlanta, GA: U.S. Department of Health and Human Services, ATSDR. TP-90/05.

Agency for Toxic Substances and Disease Registry (1990b): "Toxicological Profile for Chlorobenzene.” Atlanta, GA: U.S. Department of Health and Human Services, ATSDR. TP-90/06.

Agency for Toxic Substances and Disease Registry (1990c): “Toxicological Profile for Chloromethane." Atlanta, GA: U.S. Department of Health and Human Services, ATSDR. TP-90/07.

Agency for Toxic Substances and Disease Registry (1990d): "Toxicological Profile for 1,1-Dichloroethane." Atlanta, GA: U.S. Department of Health and Human Services, ATSDR. TP-90/12.

Agency for Toxic Substances and Disease Registry (1990e): “Toxicological Profile for Ethylbenzene." Atlanta, GA: U.S. Department of Health and Human Services, ATSDR. TP-90/15.

Agency for Toxic Substances and Disease Registry (1991a): "Toxicological Profile for Methylene Chloride." Atlanta, GA: U.S. Department of Health and Human Services, ATSDR. Draft for public comment.

Agency for Toxic Substances and Disease Registry (1991b): "Toxicological Profile for Vinyl Chloride." Atlanta, GA: U.S. Department of Health and Human Services, ATSDR. Draft for public comment.

Agency for Toxic Substances and Disease Registry (1992a): "Toxicological Profile for 2-Butanone." Atlanta, GA: U.S. Department of Health and Human Services, ATSDR. TP-91/08.

Agency for Toxic Substances and Disease Registry (1992b): "Toxicological Profile for 1,2-Dibromoethane." Atlanta, GA: U.S. Department of Health and Human Services, ATSDR. TP-91/13.

Agency for Toxic Substances and Disease Registry (1992c): “Toxicological Profile for Carbon Tetrachloride." Atlanta, GA: U.S. Department of Health and Human Services, ATSDR. Draft for public comment.

Agency for Toxic Substances and Disease Registry (1992d): "Toxicological Profile for 2-Hexanone." Atlanta, GA: U.S. Department of Health and Human Services, ATSDR. TP-91/18.

Agency for Toxic Substances and Disease Registry (1992e): "Toxicological Profile for Styrene." Atlanta, GA: U.S. Department of Health and Human Services, ATSDR. TP-91/25.

Agency for Toxic Substances and Disease Registry (1992f): "Toxicological Profile for 1,2,3-Trichloropropane." Atlanta, GA: U.S. Department of Health and Human Services, ATSDR. TP-91/28.

Agency for Toxic Substances and Disease Registry (1992g): "Toxicological Profile for Acetone." Atlanta, GA: U.S. Department of Health and Human Services, ATSDR. Draft for public comment.

Agency for Toxic Substances and Disease Registry (1992h): "Toxicological Profile for 1,2-Dichloroethane." Atlanta, GA: U.S. Department of Health and Human Services, ATSDR. Draft for public comment.

Agency for Toxic Substances and Disease Registry (1993a): "Toxicological Profile for Chloroform." Atlanta, GA: U.S. Department of Health and Human Services, ATSDR. TP-92/07.

Agency for Toxic Substances and Disease Registry (1993b): "Toxicological Profile for Tetrachloroethylene." Atlanta, GA: U.S. Department of Health and Human Services, ATSDR. TP-92/18.

Agency for Toxic Substances and Disease Registry (1993c): “Toxicological Profile for Trichloroethylene." Atlanta, GA: U.S. Department of Health and Human Services, ATSDR. TP-92/19.

Agency for Toxic Substances and Disease Registry (1993d): "Toxicological Profile for Automotive Gasoline." Atlanta, GA: U.S. Department of Health and Human Services, ATSDR. Draft for public comment. 
Agency for Toxic Substances and Disease Registry (1993e): "Technical Report for Ethylene Glycol/Propylene Glycol.” Atlanta, GA: U.S. Department of Health and Human Services, ATSDR. Draft for public comment.

Agency for Toxic Substances and Disease Registry (1993f): "Toxicological Profile for Fuel Oils." Atlanta, GA: U.S. Department of Health and Human Services, ATSDR. Draft for public comment.

Agency for Toxic Substances and Disease Registry (1993g): "Toxicological Profile for Jet Fuels JP-4 \& JP-7." Atlanta, GA: U.S. Department of Health and Human Services, ATSDR. Draft for public comment.

Agency for Toxic Substances and Disease Registry (1993h): "Toxicological Profile for Carbon Disulfide." Atlanta, GA: U.S. Department of Health and Human Services, ATSDR. Draft for public comment.

Agency for Toxic Substances and Disease Registry (1993i): "Toxicological Profile for 1,1,1-Trichloroethane." Atlanta, GA: U.S. Department of Health and Human Services, ATSDR. Draft for public comment.

Agency for Toxic Substances and Disease Registry (1993j): “Toxicological Profile for Xylenes." Atlanta, GA: U.S. Department of Health and Human Services, ATSDR. Draft for public comment.

Ahlborg UG, Lipworth L, Titus-Ernstoff L, Hsieh C-C, Hanberg A, Baron J, Trichopoulos D, Adami H-O (1995): Organochlorine compounds in relation to breast cancer, endometrial cancer, and endometriosis: An assessment of the biological and epidemiological evidence. Crit Rev Toxicol 25:463-531.

Alvares AP, Fischbein A, Anderson KE, Kappas A (1977): Alterations in drug metabolism in workers exposed to polychlorinated biphenyls. Clin Pharmacol Ther 22:140-146.

Ames BN, Gold LS (1990): Too many rodent carcinogenesis: Mitogenesis increases mutagenesis. Science 249:970-971.

Andrews LS, Snyder R (1991): Toxic effects of solvents and vapors. In Amdur MO, Doull J, Klaassen CD (eds): "Casarett and Doull's Toxicology. The Basic Science of Poisons.” Toronto: McGraw-Hill, pp 681-722.

Anttila A, Pukkala E, Sallmén M, Hernberg S, Hemminki K (1995): Cancer incidence among Finnish workers exposed to halogenated hydrocarbons. J Occup Environ Med 37:797-806.

Arınç E, Adalı O, İşcan M, Güray T (1991): Stimulatory effect of benzene on rabbit liver and kidney microsomal cytochrome P-450 dependent drug metabolizing enzymes. Arch Toxicol 65:186-190.

Åstrand I (1975): Uptake of solvents in the blood and tissues of man. A review. Scand J Work Environ Health 1:199-218.

Axelson O, Andersson K, Hogstedt C, Holmberg B, Molina G, de Verdier A (1978): A cohort study on trichloroethylene exposure and cancer mortality. J Occup Med 20:194-196.

Axelson O, Seldén A, Andersson K, Hogstedt C (1994): Updated and expanded Swedish cohort study of trichloroethylene exposure and cancer risk. J Occup Med 36:556-562.

Batist G, Schecter R, Woo A, Greene D, Lehnert S (1991): Glutathione depletion in human and in rat multi-drug resistant breast cancer cell lines. Biochem Pharmacol 41:631-635.

Berg JW, Hutter RVP (1995): Breast cancer. Cancer 75:257-269.

Blair A, Stewart PA, Tolbert PE, Grauman D, Moran X, Vaught J, Rayner J (1990): Cancer and other causes of death among a cohort of dry cleaners. Br J Ind Med 47:162-168.

Bounous G, Batist G, Gold P (1991): Whey proteins in cancer prevention. Cancer Lett 57:91-94.

Bridges BA (1986): Genetic toxicology at the crossroads: A personal overview of the deployment of short-term tests. In Montesano R, Bartsch H, Vainio H, Wilbourn J, Yamasaki H (eds): "Long-Term and Short-Term
Assays for Carcinogens: A Critical Appraisal." Lyon, France: IARC. IARC Sci. Pub. No. 83, pp 519-527.

Brown DP, Kaplan SD (1987): Retrospective cohort mortality study of dry cleaner workers using perchloroethylene. J Occup Med 29:535-540.

Campbell MK, Feuer EJ, Wun L-M (1994): Cohort-specific risks of developing breast cancer to age 85 in Connecticut. Epidemiology 5:290296.

Chiazze L, Nichols WE, Wong O (1977): Mortality among employees of PVC fabricators. J Occup Med 19:623-628.

Chiazze L, Wong O, Nichols WE, Ference LD (1980): Breast cancer mortality among PVC fabricators. J Occup Med 22:677-679.

Coleman MP, Estève J, Damiecki P, Arslan A, Renard H (1993): Breast (females). In: "Trends in Cancer Incidence and Mortality." Lyon, France: International Agency for Research on Cancer. IARC Sci. Pub. No. 121, pp $411-432$.

Coté CJ, Kenepp NB, Reed SB, Strobel GE (1976): Trace concentrations of halothane in human breast milk. Br J Anaesth 48:541-543.

Csanády GyA, Mendrala AL, Nolan RJ, Filser JG (1994): A physiologic pharmacokinetic model for styrene and styrene-7,8-oxide in mouse, rat and man. Arch Toxicol 68:143-157.

Dao TL (1969): Studies on mechanism of carcinogenesis in the mammary gland. Progr Exp Tumor Res 11:235-261.

Dao TL, Varela RM (1966): On the mechanism of inducing protection of the adrenal cortex against injury from 7,12-dimethylbenz(a)anthracene. I. Effects of inducers on benzpyrene hydroxylase activity. Cancer Res 26:1015-1021.

Davis DL, Bradlow HL, Wolff M, Woodruff, Hoel DG, Anton-Culver H (1993): Medical hypothesis: Xenoestrogens as preventable causes of breast cancer. Environ Health Perspect 101:372-377.

Dewailly E, Dodin S, Verreault R, Ayotte P, Sauvé L, Morin J, Brisson J (1994): High organochlorine body burden in women with estrogen receptorpositive breast cancer. J Natl Cancer Inst 86:232-234.

Doll R, Peto R (1987): The causes of cancer. J Natl Cancer Inst 66:1197-1312.

Eldridge SR, Gould MN, Butterworth BE (1992): Genotoxicity of environmental agents in human mammary epithelial cells. Cancer Res 52:56175621.

Engström J, Bjurström R (1977): Exposure to methylene chloride. Content in subcutaneous adipose tissue. Scand J Work Environ Health 3:215-224.

Fernández JG, Droz PO, Humbert BE, Caperos JR (1977): Trichloroethylene exposure. Simulation of uptake, excretion, and metabolism using a mathematical model. Br J Ind Med 34:43-55.

Feuer EJ, Wun L-M (1992): How much of the recent rise in breast cancer incidence can be explained by increases in mammography utilization? A dynamic population model approach. Am J Epidemiol 136:1423-1436.

Gérin M, Siemiatycki J, Kemper H, Bégin D (1985): Obtaining occupational exposure histories in epidemiologic case-control studies. J Occup Med 27:420-426.

Goldberg MS, Labrèche F (1996): Occupational risk factors for female breast cancer: A review. Occup Environ Med 53:145-156.

Gould MN (1980): Mammary gland cell-mediated mutagenesis of mammalian cells by organ-specific carcinogens. Cancer Res 40:1836-1841.

Gould MN (1982): Chemical carcinogen activation in the rat mammary gland: Intra-organ cell specificity. Carcinogenesis 3:667-669. 
Habel LA, Stanford JL, Vaughan TL, Rossing MA, Voigt LF, Weiss NS, Daling JR (1995): Occupation and breast cancer risk in middle-aged women. J Occup Environ Med 37:349-356.

Hobara T, Kobayashi H, Kawamoto T (1986): Extrahepatic organs metabolism of inhaled trichloroethylene. Toxicology 41:289-303.

Holford TR, Roush GC, McKay LA (1991): Trends in female breast cancer in Connecticut and the United States. J Clin Epidemiol 44:29-39.

Jensen AA (1991): Occupational chemicals in human milk. In Jensen AA, Slorach SA (eds): "Chemical Contaminants in Human Milk." Boca Raton: CRC Press, pp 209-214.

Kelsey JL (1993): Breast cancer epidemiology: Summary and future directions. Epidemiol Rev 15:256-263.

Klaassen CD, Eaton DL (1991): Principles of toxicology. In Amdur MO, Doull J, Klaassen CD (eds) "Casarett and Doull's Toxicology. The Basic Science of Poisons.” Toronto: McGraw-Hill, pp 12-49.

Klaassen CD, Rozman K (1991): Absorption, distribution, and excretion of toxicants. In Amdur MO, Doull J, Klaassen CD (eds): "Casarett and Doull's Toxicology. The Basic Science of Poisons." Toronto: McGraw-Hill, pp 50-87.

Kogevinas M, Ferro G, Andersen A, Bellander T, Biocca M, Coggon D, Gennaro V, Hutchings S, Kolstad H, Lundberg I, Lynge E, Partanen T, Saracci R (1994): Cancer mortality in a historical cohort study of workers exposed to styrene. Scand J Work Environ Health 20:251-261.

Koizumi A (1989): Potential of physiologically based pharmacokinetics to amalgamate kinetic data of trichloroethylene and tetrachloroethylene obtained in rats and man. Br J Ind Med 46:239-249.

Korn M, Gfrörer W, Filser JG, Kessler W (1994): Styrene-7,8-oxide in blood of workers exposed to styrene. Arch Toxicol 68:524-527.

Krieger N (1989): Exposure, susceptibility, and breast cancer risk: A hypothesis regarding exogenous carcinogens, breast tissue development, and social gradients, including black/white differences, in breast cancer incidence. Breast Cancer Res Treat 13:205-223.

Krieger N, Wolff MS, Hiatt RA, Rivera M, Vogelman J, Orentreich N (1994): Breast cancer and serum organochlorines: A prospective study among white, black, and Asian women. J Natl Cancer Inst 86:589-599.

Krishnan AV, Stathis P, Permuth SF, Tokes L, Deldman D (1993): Bisphenol-A: An estrogenic substance is released from polycarbonate flasks during autoclaving. Endocrinology 132:2279-2286.

Kvåle G, Heuch I (1987): Lactation and cancer risk: Is there a relation specific to breast cancer? J Epidemiol Community Health 42:30-37.

Löf A, Lundgren E, Byfält Nordqvist M (1986): Kinetics of styrene in workers from a plastics industry after controlled exposure: A comparison with subjects not previously exposed. Br J Ind Med 43:537-543.

Low LK, Meeks JR, Mackerer CR (1989): Health effects of the alkylbenzenes. II. Xylenes. Toxicol Ind Health 5:85-105.

Maack CA, Silva MH, Petrakis NL, Lee RE, Lyon M (1986): Procarcinogen activation by rat and human mammary extracts. Carcinogenesis 7:899-905.

MacMahon B, Lin TM, Lowe CR, Mirra AP, Ravnihar B, Salber EJ, Trichopoulos D, Valaoras VG, Yuasa S (1970): Lactation and cancer of the breast. Bull World Health Org 42:185-194.

Malins DC, Holmes EH, Polissar NL, Gunselman SJ (1993): The etiology of breast cancer: Characteristic alterations in hydroxyl radical-induced DNA base lesions during oncogenesis with potential for evaluating incidence risk. Cancer 71:3036-3043.

Mason RR, Schulte GJ (1981): Interaction of O,P'-DDT with the estrogenbinding protein (EBP) of DMBA-induced rat mammary tumors. Res Comm Chem Pathol Pharmacol 33:119-128.
Mikoczy Z, Schütz A, Hagmar L (1994): Cancer incidence and mortality among Swedish leather tanners. Occup Environ Med 51:530-535.

Morris JJ, Seifter E (1992): The role of aromatic hydrocarbons in the genesis of breast cancer. Medical Hypotheses 38:177-184.

National Cancer Institute of Canada (1993): "Canadian Cancer Statistics, 1993.” Toronto: National Cancer Institute of Canada, pp 55-59.

National Cancer Institute of Canada (1996): “Canadian Cancer Statistics, 1996.” Toronto: National Cancer Institute of Canada, pp 15-35.

National Toxicology Program (1986a): “Toxicology and Carcinogenesis Studies of Dichloromethane (Methylene Chloride) in F344/N Rats and $\mathrm{B} \mathrm{C} 3 \mathrm{~F}_{1}$ Mice (Inhalation Studies)." Atlanta, GA: U.S. Department of Health and Human Services, NTP. NIH No. 86-2562.

National Toxicology Program (1986b): "Toxicology and Carcinogenesis Studies of Benzene in F344/N Rats and B6C3F $F_{1}$ Mice (Gavage Studies)." Atlanta, GA: U.S. Department of Health and Human Services, NTP. NIH No. 86-2545.

National Toxicology Program (1986c): “Toxicology and Carcinogenesis Studies of Tetrachloroethylene (Perchloroethylene) in F344/N Rats and $\mathrm{B}^{6} \mathrm{C} 3 \mathrm{~F}_{1}$ mice (inhalation studies)." Atlanta, Ga: U.S. Department of Health and Human Services, NTP. NIH No. 86-2567.

National Toxicology Program (1986d): "Toxicology and Carcinogenesis Studies of Xylenes (Mixed) in F344/N Rats and $\mathrm{B}^{2} \mathrm{C} 3 \mathrm{~F}_{1}$ Mice." Atlanta, GA: U.S. Department of Health and Human Services, NTP. NIH No. 87-2583.

National Toxicology Program (1988): "Toxicology and Carcinogenesis Studies of Trichloroethylene in Four Strains of Rats (Gavage Studies)." Atlanta, GA: U.S. Department of Health and Human Services, NTP. NIH No. 88-2529.

National Toxicology Program (1992a): "Carcinogenesis Bioassay of 1,2Dibromoethane in F344/N Rats and $\mathrm{B}_{6} \mathrm{C} 3 \mathrm{~F}_{1}$ Mice (Inhalation Study)." Atlanta, GA: U.S. Department of Health and Human Services, NTP. NIH No. 82-1766.

National Toxicology Program (1992b): "NTP Technical Report on Toxicity Studies of N,N-Dimethylformamide Administered by Inhalation to F344/N Rats and $\mathrm{B} \mathrm{C} 3 \mathrm{~F}_{1}$ Mice." Atlanta, GA: U.S. Department of Health and Human Services, NTP. NIH No. 93-3345.

Newcomb PA, Storer BE, Longnecker MP, Mittendorf R, Greenberg ER, Clapp RW, Burke KP, Willett WC, MacMahon B (1994): Lactation and a reduced risk of premenopausal breast cancer. N Engl J Med 330:81-87.

Paci E, Buiatti E, Costantini AS, Miligi L, Pucci N, Scarpelli A, Petrioli G, Simonato L, Winkelmann R, Kaldor JM (1989): Aplastic anemia, leukemia and other cancer mortality in a cohort of shoe workers exposed to benzene. Scand J Work Environ Health 15:313-318.

Pelkonen O, Raunio H (1995): Individual expression of carcinogenmetabolizing enzymes: Cytochrome P4502A. J Occup Environ Med 37:19-24.

Pellizzari ED, Hartwell TD, Harris BSH III, Waddell RD, Whitaker DA, Erickson MD (1982): Purgeable organic compounds in mother's milk. Bull Environ Contam Toxicol 28:322-328.

Perbellini L, Mozzo P, Brognone F, Zedde A(1986): Physiologicomathematical model for studying human exposure to organic solvents: Kinetics of blood/tissue n-hexane concentrations and of 2,5-hexanedione in urine. Br J Ind Med 43:760-768.

Petrakis NL (1977a): Breast secretory activity in nonlactating women, postpartum breast involution, and the epidemiology of breast cancer. Natl Cancer Inst Monogr 47:161-164.

Petrakis NL (1977b): Genetic factors in the etiology of breast cancer. Cancer 39:2709-2715. 
Petrakis NL (1986): Physiologic, biochemical, and cytologic aspects of nipple aspirate fluid. Breast Cancer Res Treat 8:7-19.

Petrakis NL, Dupuy ME, Lee RE, Lyon M, Maack CA, Gruenke LD, Craig JC (1982): Mutagens in nipple aspirates of breast fluid. In: "Banbury Report 13: Indicators of Genotoxic Exposure." Cold Spring Harbour, NY: Cold Spring Harbour Laboratory, pp 67-82.

Petrakis NL, Gruenke LD, Beelen TC, Castagnoli N Jr, Cymerman Craig J (1978): Nicotine in breast fluid of nonlactating women. Science 199:303305.

Petrakis NL, Gruenke LD, Craig JC (1981): Cholesterol and cholesterol epoxides in nipple aspirates of human breast fluid. Cancer Res 41:25632565.

Petrakis NL, Maack CA, Lee RE, Lyon M (1980): Mutagenic activity in nipple aspirates of human breast fluid. Cancer Res 40:188-189.

Poland A, Smith D, Kuntzman R, Jacobson M, Conney AH (1970): Effect of intensive occupational exposure to DDT on phenylbutazone and cortisol metabolism in human subjects. Clin Pharmacol Ther 11:724-732.

Reitz RH, McDougal JN, Himmelstein MW, Nolan RJ, Schumann AM (1988): Physiologically based pharmacokinetic modeling with methylchloroform: Implications for interspecies, high dose/low dose, and dose route extrapolations. Toxicol Applied Pharmacol 95:185-199.

Rockhill B, Newman B, Moorman P, Millikan R, Weinberg C (1996): Summary attributable fraction and breast cancer risk factors. Am $\mathrm{J}$ Epidemiol 143:S58.

Ruder AM, Ward EM, Brown DP (1994): Cancer mortality in female and male dry-cleaning workers. J Occup Med 36:867-874.

Sato A, Nakajima T (1987): Pharmacokinetics of organic solvent vapors in relation to their toxicity. Scand J Work Environ Health 13:81-93.

Sato A, Nakajima T, Fujiwara Y, Murayama N (1975): Kinetic studies on sex difference in susceptibility to chronic benzene intoxication -with special reference to body fat content. Br J Ind Med 32:321-328.

Shannon SH, Haines T, Bernholz C,Julian JA, Verma DK, Jamieson E, Walsh C (1988): Cancer morbidity in lamp manufacturing workers. Am J Ind Med 14:281-289.

Schecter RL, Alaoui-Jamali MA, Batist G (1992): Glutathione S-transferase in chemotherapy resistance and in carcinogenesis. Biochem Cell Biol 70:349-353.

Siemiatycki J, Day NE, Fabry J, Cooper JA (1981): Discovering carcinogens in the occupational environment: A novel approach. J Natl Cancer Inst $66: 217-225$

Sim MR, McNeil JJ (1992): Monitoring chemical exposure using breast milk: A methodological review. Am J Epidemiol 136:1-11.

Soto AM, Justicia H, Wray JW, Sonnenschein C (1991): p-Nonyl-phenol: An estrogenic xenobiotic released from "modified" polystyrene. Environ Health Perspect 92:167-173.

Spirtas R, Stewart PA, Lee JS, Marano DE, Forbes CD, Grauman DJ (1991): Retrospective cohort mortality study of workers at an aircraft maintenance facility. I. Epidemiological results. Br J Ind Med 48:515-530.

Statistics Canada (1990): "Women in Canada: A Statistical Report." 2nd ed. Ottawa, Ontario: Ministry of Supply and Services Canada. Catalogue 89-503E.
Stayner L, Elliott L, Blade L, Keenlyside R, Halperin W (1988): A retrospective cohort mortality study of workers exposed to formaldehyde in the garment industry. Am J Ind Med 13:667-681.

Stayner L, Smith AB, Reeve G, Blade L, Elliott L, Keenlyside R, Halperin W (1985): Proportionate mortality study of workers in the garment industry exposed to formaldehyde. Am J Ind Med 7:229-240.

Stevens RG, Moolgavkar SH, Lee JAH (1982): Temporal trends in breast cancer. Am J Epidemiol 115:759-777.

Stewart PA, Stewart WF (1994a): Occupational case-control studies: II. Recommendations for exposure assessment. Am J Ind Med 26:313-326.

Stewart WF, Stewart PA (1994b): Occupational case-control studies: I. Collecting information on work histories and work-related exposures. Am J Ind Med 26:297-312.

Swanson GM, Ragheb NE, Lin C-S, Hankey BF, Miller B, Horn-Ross P, White E, Liff JM, Harlan LC, McWhorter WP, Mullan PB, Key CR (1993): Breast cancer among black and white women in the 1980s. Cancer 72:788-798

Taneko T, Wang P-Y, Sato A (1994): Partition coefficients of some acetate esters and alcohols in water, blood, olive oil, and rat tissues. Occup Environ Med 51:68-72.

Thomas DB, Noonan EA (1993): Breast cancer and prolonged lactation. Int J Epidemiol 22:619-626.

Toftgård R, Gustafsson J-Å (1980): Biotransformation or organic solvents. Scand J Work Environ Health 6:1-18.

Vorherr H (1974): "The Breast. Morphology, Physiology and Lactation." New York: Academic Press, pp 48-50.

Wassermann M, Nogueira DP, Tomatis L, Mirra AP, Shibata H, Arie G, Cucos S, Wassermann D (1976): Organochlorine compounds in neoplastic and adjacent apparently normal breast tissue. Bull Environ Contam Toxicol $15: 478-484$

Wolff MS (1983): Occupationally derived chemicals in breast milk. Am J Ind Med 4:259-281.

Wolff MS, Toniolo PG, Lee EW, Rivera M, Dubin N (1993): Blood levels of organochlorine residues and risk of breast cancer. J Natl Cancer Inst $85: 648-652$.

Wong O (1990): A cohort mortality study and a case-control study of workers potentially exposed to styrene in the reinforced plastics and composites industry. Br J Ind Med 47:753-762.

Wong O, Trent LS, Whorton MD (1994): An updated cohort mortality study of workers exposed to styrene in the reinforced plastics and composites industry. Occup Environ Med 51:386-396.

Wun L-M, Feuer EJ, Miller BA (1995): Are increases in mammographic screening still a valid explanation for trends in breast cancer incidence in the United States? Cancer Causes and Control 6:135-144.

Yap PL, Miller WR, Humeniuk V, Pryde EAD, Mirtle CL, McClelland DBL (1981): Milk protein concentrations in the mammary secretions of nonlactating women. J Reprod Immunol 3:49-58.

Yuan JM, Yu MC, Ross RK, Gao YT, Henderson BE (1988): Risk factors for breast cancer in Chinese women in Shanghai. Cancer Res 48:19491953. 